\title{
THE INTERNAL AND EXTERNAL FACTORS OF THE PROTAGONIST'S REPENTANCE IN THE MOVIE SCRIPT SECOND ACT BY JUSTIN ZACKHAM AND ELAINE GOLDSMITH-THOMAS
}

\author{
Susi Ekalestari, Alma Rizka Siregar \\ Faculty of Literature, Universitas Islam Sumatera Utara \\ Medan, Indonesia \\ e-mail: susi.ekalestari@sastra.uisu.ac.id
}

Received: 2021-08-19

Accepted: 2021-11-08

\begin{abstract}
This research is conducted to analyze the internal and external factors of the protagonist's repentance from Second Act movie written by Justin Zackham And Elaine Goldsmith-Thomas. The internal factors of repentance are self evaluation, self-motivation, self-control, knowledge, regret, hatred towards the sin, and returns to god's power and will. The external factors of repentance are peer support, social support, intense guidance, and stimulus. It is in accordance to the theory proposed by Fachitiandi. This study uses qualitative descriptive method because the process and the result are accomplished descriptively and the focus goes to the analysis of social phenomena conducted and experienced the main character. Repentance is not only found in a literary text but also in social reality, therefore this research is important enough for the readers to maintain a good life by avoiding things contrary to social norms. After the analyzing, it is found that internal factors of the Protagonist's repentance in the movie script are self-evaluation, self-motivation, and knowledge, while, the external factors of the protagonist's repentance are peer of support and social of support.
\end{abstract}

Keywords: repentance, internal factors, external factors

\section{Introduction}

Second Act tells a woman in her forties who successfully pursues a second chance at a corporate career after a friend creates a fake resume and credentials for her. Second Act is a 2018 American romantic Second Act comedy film was directed by Peter Segal and written by Elaine Goldsmith-Thomas and Justin Zackham. It stars Jennifer Lopez, Leah Remini, Vanessa Hudgens, Treat Williams and Milo Ventimiglia. The film received mixed reviews from critics, with praise of Lopez's performance, and grossed over US\$72 million worldwide. This comedy drama genre film tells the story of women's struggles to change their own destinies. Second Act is an inspirational comedy starring Jennifer Lopez as Maya, Forty-year-old woman who struggles with frustration at not achieving more in her life. As an experienced, responsive, perceptive employee, she does not get a job promotion, simply because she does not have a college degree. She is an employee in a large shop who is reassembling her life and lifestyle. All of 
which allowed her to prove to Madison Avenue that smart, experienced, self-taught field woman were worth a bachelor's degree. With the help of social media and an attractive resume, Maya has managed to take advantage of new opportunities in her life by applying for and becoming a very influential executive position.

The researchers prefer to analyze the internal and external factors of the protagonist's repentance in the movie "Second Act" by Justin Zackham because the researchers are interested in digging into the daily life of the protagonist which cause her having repentance in her life. Another reason why the researchers choose to analyze this Second Act story is that she is eager to know the moral lesson that might be obtained after analyzing the protagonist's repentance in the movie. Therefore, the subject matter that would be analyzed in this research is limited on to the internal and external factors of repentance of the protagonist. Surely, every human being has made mistake in his or her life and repentance always come to those who meets the factors that make him or her realize about his or her sin. The factor itself might come from internal force or external force.

\section{Literature Review}

According to Abdullah (1999), repentance is a human character and obligation to Allah SWT. Individuals must repent so that they do not return to despicable acts. The decision to repent must be taken in order to remain in the path of Allah SWT. Repentance is a form of virtue that must be done by man to ask forgiveness of Allah SWT to escape from sin. In the process of repentance, the individual can return to sin. Repentance is a form of benevolent that humans must do to ask Allah SWT forgiveness for their sinful acts that have been committed. Decision making that is carried out requires a strong determination from within the individual.

Repentance in Islam means tawba. Al-Ghazali (2013) defines tawba as turning away from the sin you have committed, preventing yourself from repeating it in the future, and correcting the mistakes that you have made due to not performing good deeds in the past. Tawba concerns the act of leaving God's prohibitions and following His commands. Repentance means that humans strive to purify themselves and to return to their original disposition in a sinless state (also known as fitra).

The pillars of tawba show the sincerity of repentance. A person who truly repents shows remorse for the thoughts and bad deeds they have committed and are determined to put aside those wrong doings. Al Jauziyyah (2014) identifies six characteristics of a repentant person: (1) maintaining relationships with pious people and avoiding those who have negative influences; (2) improving their behavior; (3) overcoming sin and accepting virtues with an open mind; (4) feeling constant fear of God's wrath and punishment; (5) detachment from worldly desires and the tendency. Towards divine values; and (6) being mindful of their thoughts and actions.

There are certain conditions that should be satisfied for one's repentance to be accepted. Al-Utsaimin (2015) defines five such conditions of repentance. First, the performance of tawba should be solely intended to expect repentance and forgiveness from Allah instead of for other reasons (e.g., expecting praise from others). Second, one should feel remorse for having committed acts that are prohibited in Islam. Third, there should be a sincere intention to stop committing misdeeds. It is the most important requirement of tawba. Fourth, someone should have the determination not to repeat the sin in the future. If a person intends to repeat it again once they have a chance, then their 
repentance will not be accepted. And fifth, tawba should be performed before it is too late.

The psychological dynamics of repentance are divided into two stages. The first stage is intention formation. At this stage, participants realize that the difficulties in life they experience are a consequence of past sins. Then, the participant compared his life the situation with other people who he thought had a better life. Participants then concluded that they will get a better life if they repented of their sins. That conclusion gave the participants the intention to repent. The second stage is the emergence of repentant behavior. Repentant behavior appears after receiving support from peers and routine religious education. If both are not there, then the individual will return to committing immorality, especially if he gathers with friends of the immoral perpetrator.

Certain causes that trigger individuals to repent according to Lewin and Keller (1992) are problems. Problems can cause fear in individuals. This fear then makes the individual change their behavior. Based on preliminary research data, it was found that fear makes people aware of their mistakes and sins that have been committed. There must be some factors causing repentance.

Fachitiandi (2018) finds there are two factors of repentance, it is internal and external factors. Internal Factor of repentance is divided into 4 categories: selfevaluation, self-motivation, self-control, and knowledge. External factor of repentance is divided into 4 categories: peer support, social support, intense guidance, and stimulus.

\subsection{Internal Factors of Repentance}

Internal factors are factors that come from within the individual and support the repentance process to become a better person (Setiana, 2017). According to Fachitiandi (2018) the internal factors have 4 sub-categories they are self-evaluation, selfmotivation, self-control, and knowledge.

\section{Self-Evaluation}

Individuals will know their mistakes and shortcomings after realized, then will plan to change their behavior and mistakes into right actions. Individuals will evaluate themselves when individuals get learning from experiences that make individuals aware of their shortcomings Fachitiandi (2018).

Iqbal (2012) states that core self-evaluation is a personality trait that includes self-evaluation, their abilities, and control over their abilities. Individuals with high selfevaluation will feel confident and think positively of themselves while people with low self-evaluation will be less confident.

Judge and Bono (2003) states that individual will able to influence people's judgments about themselves, the world and others, and do so consciously. Individuals with positive self-evaluation will be more effective in overcoming obstacles, using better problem-solving strategies. In addition, they will be more effective in positions requiring positive interpersonal relationships or stress tolerance.

\section{Self-Motivation}

According to Latham and Locke (1979) motivation will improve if people have demanding but agreed goals and receive feedback. Motivation is concerned with the strength and direction of behavior and the factors that influence people to behave in certain ways. The term 'motivation' can refer variously to the goals individuals have, 
the ways in which individuals chose their goals and the ways in which others try to change their behavior. In general, motivation means something that encourages action. Motivation is all verbal, physical, or psychological things that make someone do something in response. Motivation also means Individuals who have self-motivation to do good deeds and learn to be self-capable will continue to experience intellectual development which will be able to change their behavior to be good. Motivation is a want and will drive power that eventually someone acts or behaves. He added that every motivation has a specific goal to be achieved.

\section{Self-Control}

According to Calhoun \& Acocella (1990) individuals who have self-control will avoid things that can trigger bad deeds so that they will be on the right path. Self-control is useful for individuals in the environment or group to restrain their desires so as not to deviate from the values that exist in individuals so that individuals can control themselves to avoid deviant behavior. Self-control is often defined as the ability to organize, guide, regulate and direct forms of behavior that can lead to positive consequences. Self-control means self-regulating one's own behavior.

Self-control means being fully aware of what to do. Self-control also means being able to put off short-term pleasure to get something better for the long term. In fact, self-control is the ability to restrain appetite or desire to limit the benefit of the egocentric (self-centered) which is excessive. Self-control can be seen in difficult situations that involve emotions (Srijanti, 2007). Srijanti also explains that anger is the most difficult mood to control. When someone gets angry, his or her mind is filled by self-justification so that he or she has very convincing reason to vent anger. In a situation of being angry, someone will vent his or her anger with various forms of both positive and negative actions.

According to Ghufron and Risnawati (2011) self-control is a behavior control activity, behavior control means taking considerations before deciding something to act. The situation here concerns a very broad range of events and all the things that will be caused by these events. In that sense, people who have self-control can anticipate, interpret and make decisions related to the event.

\section{Knowledge}

The knowledge gained will make individuals evaluate self-deficiencies and the consequences of a behavior that can lead to new attitudes to behave, and can make individuals obey the prohibitions and rules of Islamic teachings conveyed by a teacher who will form norms in individuals. Knowledge is the result of a series of how we process raw data into useful information. Data and information are further filtered based on facts, truths, beliefs, judgments, experiences, and expertise of the recipient (Ajzen \& Madden, 1986).

Furthermore, Knowledge is a combination of instincts, ideas, rules, and procedures that direct actions or decisions. Information combined with past experience and expertise will provide valuable knowledge (Mulyanto, 2009).

\subsection{External Factors of Repentance}

External factors are factors that come from outside that support the repentance process to become a better person (Setiana, 2017). According to Fachitiandi (2018) the 
external factors have 4 sub-categories they are peer support, social of support, intense guidance, and stimulus.

\section{Peer Support}

Mead, et.al (2001) say that peer support is a process of giving and receiving assistance based on mutual respect, sharing of responsibility and providing mutual support that is helpful. Peer support is also a condition in which a person develops due to his decisions, feels accepted and supported to achieve his goals.

Furthermore, according to Samsunuwiyati (2005) states that peer support has a strong influence on behavior change. If his or her friend is bad, then the individual will be bad. However, if his \her friend is good, then the individual will be good. Peers who have the same behavior can provide encouragement to behave and can involve relatively large cohesiveness.

Meanwhile, Solomon (2004) explains that peer support is a form of social support that is done to make someone better and become a desirable person. Peer support is also like information from other people who in this context are peers, that someone is loved and cared for, valued and has valuable values.

\section{Social Support}

Solomon (2004) explains that social support is the existence of other people who can be relied on, who care, are valuable and love someone. Social support can come from family members, friends, colleagues and the religious community that is followed. Social support can be in the form of information provided direct recommendations and directions. Meanwhile, according to Cohen (2004) social support is support provided to make someone better, both in the form of psychological support and material support.

Furthermore Taylor (2009) states that social support is a relationship process formed from individuals with the perception that someone is loved, valued and loved, to provide assistance to individuals who experience pressures in their lives. Social support is information from others to be loved and cared for, respected and appreciated, and is part of communication and mutual obligations. Social support can come from parents, spouses, family, friends, the social environment and society. Individuals with high social support will tend to be able to cope with stress when they face stressful experiences and may be successful in coping.

Meanwhile, according to Cohen et.al (2004) the term social support refers to social resources that are available to a person or that are actually provided to that person by non-professionals, either in the form of support in groups or mutual assistance between individuals. People with high social support believe that they are loved, valued, and part of social networks, such as family or community organizations, which can help when needed.

\section{Intense Guidance}

To carry out the plan for repentance requires someone who can guide and teach individuals to act in real ways such as teaching prayers and read the Al-qur'an. Guidance must be continuous until the individual can take an action. Education and learning under intense guidance have major benefits and effects on changes in behavior, intellectual abilities, emotional and spiritual abilities (Suderajat, 2001).

Guidance is the process of providing assistance carried out by an expert to a person or several individuals, whether children, adolescents or adults so that the person 
being guided can develop their own abilities and independently by utilizing individual strengths, existing, facilities and can be developed based on prevailing norms. Intense Guidance itself is a process of giving assistance performed by a skilled person to an individual or group of people in order to develop their self-ability based on the prevailing norms (Prayitno and Amti, 2004). Guidance is assistance given to individuals or groups of individuals in avoiding or overcoming their life's difficulties, so that individuals can achieve prosperity in their life. In relation to education, guidance is an integral part of any educational program (Walgito, 2005).

\section{Stimulus}

When the individual is aware of his or her shortcomings and mistakes, the individual will look for an action or a way out to solve the anxiety, which will then act real. Lewin \& Keller (1992) state that in the theory of change, there are three main phases in the change process, namely the Unfreezing (Disbursement) stage, it is the stage to change conditions that cause anxiety and imbalance.

When planning has been made, but when there is no stimulus to encourage a change response, it cannot be implemented. With the stimulus given to individuals, individuals who have planned will be encouraged to respond or carry out their plans. When received by the individual, a strong stimulus will generate a response to action (Walgito, 2010).

\section{Research Method}

Study design is a master plan a framework for action and methods as well as specific procedures and analyzed the research or information need (Maryani, 2015). In this research, the researchers use qualitative descriptive method to analyze the data. Qualitative descriptive method is to analyze the form of description, not a number or coefficient of relationship between variables. Therefore, the research design adopted in this study is descriptive qualitative because the process of the analysis and the findings are accomplished descriptively (Aminuddin, 1990). The data is obtained from the script of the movie in the form of quotation which then is analyzed descriptively in accordance with the theories adopted in this research.

\section{Discussion}

Internal Factors of the Protagonist's repentance that is found in the movie script are self-evaluation, self-motivation, and knowledge. While, the external factors of the protagonist's repentance that is found in the movie script are: peer of support and social of support.

\subsection{The Internal Factors of Repentance}

The internal factors of repentance related to the story including self-evaluation, self-motivation, and knowledge.

\subsubsection{Self-Evaluation}

Self-evaluation is when someone knows and evaluates himself or herself from previous mistakes which then he or she gets life teaching from their shortcomings. The protagonist in this film does experience what is called self-evaluation. It happens when she tells honestly what she had actually done in the past in front of many people. What 
she had done was a mistake. This was done because she has evaluated herself for her mistakes. It can be seen in the following quotation:

"Thank you, Zoe. Anderson. Thank you for giving me a chance. Not everyone in corporate America does that. There are people out there who were never given an opportunity because they couldn't afford the right college, and never got that degree that would open the door. And you're right, Zoe, maybe I did get where I am today because I wasn't afraid to tell the truth. Even if it hurts. And the truth is ... the truth is ..., The truth is ....."

For the past fifteen years I wasa checker then assistant manager at the local Value Club, in Forest Hills........ invented my resume. My degrees. And my accomplishments. ......It's what i thought I needed to do to get in the door. To be good enough. I thought none of you would have looked at me if you knew the truth.

So I gave you a version of me. But no relationship built on a lie can ever survive.........So, for better or worse, I have to be who I really am. And ... I'm Maya from Queens. That's the real me. ........ What I did was wrong. I'm sorry. I shouldn't have lied to any of you. Chase? Ariana? It's all yours.

(Zackham, 2017: 108-110)

The quotation above describes that Maya had a bad experience in her past. It was when she was forced to make a fake resume when she was finding a job. If she made the real resume, she would not get the job, therefore, she had to lie. She made a new version of her own resume which showed that she graduated from Harvard University with cum laude predicate and was fluent in Mandarin. With the fake resume, she finally got a job at a large company engaged in the beauty sector. In the last quotation she made a public speech, she said that she had made a mistake by falsifying her resume to get the job she wanted, and finally she realized that it was wrong. Her consciousness of her mistake shows that self-evaluation happens to the protagonist.

Furthermore, she gets so sorry about her past fault in making a fake resume. This happens when she realizes that it gives bad impact to her occupation. The following is the quotation:

That was F\&C. They want to hire me....... I am. Except for the whole lying about every last part of my life thing.

....... I admit that the way I got in was less than honest, but what I did in that room ... I can do this.

(Zackham, 2017: 26-27, 30)

All of it. I donk't make products, Zoe. That'snot really what I do.

(Zackham, 2017: 105)

The quotation above explains that Maya really does self-evaluation, especially on her fake resume. She feels guilty and regrets her actions over the fake resume. Finally, it has an impact on the performance she produced at the company where she was working. She was hired by the company because of the fake resume she made. She 
The Internal and External Factors of The Protagonist's Repentance in The Movie Script Second Act by Justin Zackham and Elaine Goldsmith-Thomas, Alma Rizka Siregar, Susi Ekalestari

realizes that all result of her duty is also fake because she got her duty because of fake resume.

Another form of Maya's self-evaluation can also be seen when she regrets her action in leaving her child in an orphanage. It is explained in this following quotation:

\subsubsection{Self-Motivation}

The protagonist always does self-motivation in her life. She always motivates herself every day she wakes up from her sleep. She also always says to herself to take the opportunity or any second chance that come to her life. No one can stop her or him except himself or herself. This is proved by the following quotation:

Every day you wake up and have a second chance to do whatever you want, to be whoever you want. The only thing stopping you, is you.

(Zackham \& Thomas, 2017: 116)

The quotation above emphasizes that we are the only people who can stop us and motivate us not others. Motivating yourself is very important to do because to achieve what we want requires strong self-motivation. We should always take any second chances coming to our life.

Self-motivation also occurs when Maya is challenged by her boss to make something new. She accepts the challenge. Then, she motivates herself to do the challenge.

\section{ANDERSON}

I've tasked two teams with two different challenges. Zoe's team set out to create a slightly more organic alternate to an existing product line, while Maya's task was to create a completely new one. A totally green line. Zoe? (Zackham\& Thomas, 2017: 96)

\section{MAYA}

Well, my partners, Chase Iskowitz, Ariana Ng, and I have challenged ourselves to think outside the box. And in keeping with that theme, we'd like to move our presentation outside.

(Zackham \& Thomas, 2017: 97)

I think I just wanted to try it to prove to myself that I could. (Zackham\& Thomas, 2017: 105)

The quotation above shows that her boss gave Maya the challenge of producing a product that was actually made from 100 percent natural ingredients. It was not an easy challenge because it was very difficult to find a natural formula for the product. Still, Maya did not want to give up even though the challenge from her boss looks tough, she believed that she can do the challenge.

\subsubsection{Knowledge}

Knowledge is a combination data, information, ideas, and procedures that will provide valuable knowledge. Maya has knowledge of how a product is produced and so that the product is in demand in the market. Due to the experience of Maya who has worked as an assistant manager for decades in a department store, she could fulfill what her boss asked. 
It's close enough. you don't want your consumers to lose faith in you. i'm just saying aim higher. you can't say "all-natural" on the front of bottle, then have a list of parabens, and ..... other chemicals on the back. People don't want to "probably not"get cancer from skin cream. (Zackham\& Thomas, 2017: 40)

Okay, let's start with our goal:(writes)"Face cream. Moisturizer. Sunblock." It's gotta be one hundred percent organic.

(Zackham\& Thomas, 2017: 46)

Forget the numbers. That's what got us in this mess in the first place. I got a good feeling about this. We're making one product that does everything. Rejuvenates, blocks the sun, moisturizer the whole body. I mean think about it, how ridiculous is it that we have a different cream for everybody part. It's stupid.

(Zackham\& Thomas, 2017: 80)

From the quotation above, it is explained that Maya and her team started to make several products namely face cream, moisturizer, and sunblock. All those products must be made of one hundred percent natural ingredients because she did not want the buyers of their products to get skin cancer because of deceptive product claims. She wanted to make a new breakthrough by combining these three products in one product but had three benefits at the same time, namely rejuvenating, moisturizing the whole body, and blocking sunlight. It is emphasized with the following quotation:

When I was a little girl, my grandma gave me this potted plant and told me this story. After we dropped the bomb, the military sent a team to Japan to make sure the radiation had depleted. The only thing they found that hadn't been destroyed was one single living tree. The leaves were already growing back. A month later it flowered. The citizens built a temple around it, and the soldiers took clippings from it. One of those soldiers was my grandpa. The Japanese call it gin kyo which means silver apricot.

(Zackham \& Thomas, 2017: 90)

I think $\mathrm{F} \& \mathrm{C}$ has an opportunity to double our market share by giving people what they want, what they need; one organic product that does it all. And that product comes from this very Ginkgo tree. All-In-One Ginkgo Cream. It's a revolutionary idea that we think. And signify a new era in skincare.

(Zackham \& Thomas, 2017: 99)

The quotation above explains that when Maya was challenged by her boss to make a product using 100 percent natural ingredients, she remembered that her grandmother had given her a plant called ginkgo. Ginkgo leaf is believed to be radiation resistant and is the only plant that can grow after the city of Hiroshima was destroyed by a nuclear bomb. Ginkgo leaf is also good for skin. Then, Maya and her team made a research on ginkgo. They got the result that the ginkgo leaves can be extracted to be the main ingredient in the manufacture of their natural products. With this revolutionary 
The Internal and External Factors of The Protagonist's Repentance in The Movie Script Second Act by Justin Zackham and Elaine Goldsmith-Thomas, Alma Rizka Siregar, Susi Ekalestari

invention they won the challenge and made the natural product of the ginkgo tree, the latest invention in natural beauty products.

\subsection{The External Factors of Repentance}

The external factors of repentance related to the story including peer of support, and social of support.

\subsubsection{Peer Support}

Peer of support is process of giving and receiving assistance from other people who in this context are peers such as someone is loved and cared for, valued and has valuable values. Maya has a peer, Joan, who always supports her in sad and happy situations. Maya and Joan always share whatever stories they experience in their lives. Joan always gives advice and suggestion to Maya, especially when Maya has to be moved to a lower position in the company. Joan encourages Maya not to give up because Maya has the ability to get another job elsewhere.

\section{JOAN}

Relax. He used your legal ... Maria de la Rosalinda de la whatever name, and put you up for some jobs.

$$
\text { MAYA }
$$

I didn't ask him to.

\section{JOAN}

So blow it off. Become the knight of laxatives. (Zackham\& Thomas, 2017: 18)

The quotation above explains that Joan gives Maya the spirit not to give up and helps Maya create the fake resume. Joan is the closest person to Maya. They always share their life stories one each other. Joan is a person who is always there and always provides solutions for Maya when she is in trouble. Joan has a son named Dilly, when Maya is transferred to a lower position in the company where she and Joan work. Joan is the one who grieved the most about it. She tells his son Dilly to make an attractive fake resume even though they have to forge a Maya's identity because Maya does not have an academic degree. They created a fake resume in such a way that she could be accepted in a big company.

The lie opened the door, but it wasyou who got that job. You know you can do this, and we both know you may never get another chance. (Zackham\& Thomas, 2017: 27)

Oh, right - it's way better to lug your past around like a cross and bury your self-esteem in your career than ever forgive yourself for things that happened when you were practically a child.

(Zackham\& Thomas, 2017: 46)

The quotation above reaffirms Joan's form of peer support. Joan convinces Maya to follow her advice to create a fake resume even though Maya initially refuses it because she knows that it is wrong. Joan tells Maya if she does not apply for the job with the fake resume, she will not get a second chance to get another job. Moreover, Maya does not have an academic degree, and considering that Maya is 40 years old, it is very difficult for her to find a job. So, it is the only choice Maya has, to be able to 
survive in the midst of the rigors of life in New York City. Although the social support provided by Joan to Maya is a form deviation. However, it is given to help her.

\subsubsection{Social Support}

Social support is support which can come from family members, friends, colleagues and the religious community that provide assistance to individuals who experience pressures in their lives.Social support can be in the form of information providing direct recommendations and directions.

\section{$\mathrm{ZOE}$}

So, we hired a woman who has achieved her success not by going by the book, but by using her gut. (she looks to Maya) Someone not afraid to tell the truth, even if that truth hurts. Ladies and Gentleman, Maya Vargas. (Zackham \& Thomas, 2017: 108)

The quotation above explains that when Zoe introduces Maya to the audience. She is very proud of Maya for having achieved success not by just reading a book, but by using her instincts. Maya is also not afraid to tell the truth, even if the truth hurts. Zoe always gives Maya positive support. Zoe is actually Maya's daughter whom Maya once left in an orphanage. They both do not know this, and finally the truth is revealed when Maya works at Zoe's place as the deputy director of the company.

\section{Conclusion}

After doing the analysis about the protagonist's internal and external factors of the protagonist's repentance, there are several points as the conclusion of this research. They are presented below:

1. Someone might have repentance due to two factors. They are internal factor and external factor.

2. Dominantly, a success is obtained after some challenges come to one's life. The challenge looks very difficult to achieve but a strong determination will trigger a person to succeed.

3. Generally, to get a good job, we must need a good academic degree or academic resume.

4. Distress might trigger a person to do something undesirable.

5. Every human being might have trouble in their life but solution must be there.

6. Every human being must struggle in their life to achieve what she or he dreams.

7. Repenting and evaluating ourselves are very important in our life even though we have committed major sins.

\section{References}

Abdulllah. Z. A. (1999). Kumpulan Khutbah Jum'at Pilihan. Bandung:Pustaka Setia

Ajzen, I., \& Madden, T. J.(1986). Prediction of Goal Directed Behaviour: Attitudes Intention and Perceived Behaviour Control. Journal of Experimental Social Psychology, 22(3), 453-474

Al-Ghazali. (2013). Ihya Ulumiddin: Menghidupkan Kembali Ilmu-Ilmu Agama. Pintu Taubat. Jakarta: Republika.

Al-Jauziyyah, I. Q. (2014). Ensiklopedia Taubat. Dari Dosa Menuju Syurga (A. Dzulfikar (trans.)). Depok: Keira Publishing.

Al-Utsaimin, M. B. S. (2015). Syarahriyadhusshalihin. Jakarta: Darus Sunnah. 
The Internal and External Factors of The Protagonist's Repentance in The Movie Script Second Act by Justin Zackham and Elaine Goldsmith-Thomas, Alma Rizka Siregar, Susi Ekalestari

Aminuddin. 1990. Penelitian Kualitatif Dalam Bidang Bahasa dan Sastra. Malang: Yayasan Asih Asah Asuh Malang (YA 3 Malang).

Calhoun, J.F \& Accocella J.R. (1990). Psychology of Adjustment and Human Reliationship. New York: M.c Graw Hill Inc.

Cohen, S. (2004). Social Relationship and Health. American Psychologist, 59(8), 676684.

Fachitiandi, A.R. \& A. Satria. P. (2018). Psychological Dynamics of Repentance Processess. International Journal Of Multiscience. Vol. 1(2). https://multisciencejournal.com/index.php/ijm/article/view/85

Ghufron, M. Nur \& Rini Risnawita S. (2011). Teori-Teori Psikologi (Yogyakarta: ArRuzz Media).

Iqbal, Y. (2012). Impact of Core Self Evaluation(CSE) on Job Satisfaction in Education Sector of

Pakistan. Journal of Global Strategic Management, 12(1): 132-139.

Judge, T.A \& Bono, J.E. (2003). Relationship of Core Self Evaluations Traits With Job Satisfaction and Job Performance: A Meta- Analysis. Journal of Applied Psychology, Vol 86: 80-92.

Latham, G and Locke, R (1979) Goal setting - a Motivational Technique That Works. Organizational Dynamics, Autumn, pp 68-80

Lewin, K \& Keller.(1992). Instructional Design Theory and Models: an Overview of Their Current Status, Charles M. Regeluth. London: Lawrence Erlbaum Associates

Maryani, D. (2015). Political Marketing. International Journal of Scientific \&Technology Research Volume. http://eprints.ipdn.ac.id/5430/1/The-AnalysisOf-Political-Marketing-\%281\%29.pdf

Mead, S., Hilton, D.,\& Curtis,L. (2001). Peer Support: a Theoritical Perspective. Psychiatri Rehability, 25(2), 1-29.

Mulyanto, Agus.(2009). Sistem Informasi Konsep \& Aplikasi.Yogyakarta:Pustaka Pelajar

Prayitno \& Anti, Erman. (2004). Dasar-dasar Bimbingan dan Konseling. Jakarta: Rineka Cipta.

Samsunuwiyati, M.(2005). Psikologi Perkembangan.Bandung : Pt Remaja Rosda Karya

Setiana.M.A.T. (2017). Faktor Internal Dan Eksternal Yang Mempengaruhi Motivasi Peserta Mengikuti Pelatihan Memasak Di Lkp Ions. Yogyakarta. Program Studi Pendidikan Teknik Boga Fakultas Teknik Universitas Negeri Yogyakarta 2017

Solomon, P. (2004). Peer Support/ Peer Provide Service Underlying Processes, Benefits and Critical Ingredients. Psychiatric Rehabilitation Journal, 27(4), 392-401.

Srijanti, et al,. (2007). Etika Berwarga Negara. (2nded). Jakarta: Salemba Empat.

Suderajat, A.(2001). Pelayanan di Perpustakaan Sebuah Jasa:Infor Persada Media

Informasi Perpustakaan. Yogyakarta: Sanata Dharma

Taylor, S.E. (2009). Health Psychology. New York : Mc Graw Hill

Walgito, Bimo. (2005). Bimbingan dan Konseling Islam Yogyakarta: Andi Offset.

Walgito, B.(2010). Pengantar Psikologi Umum (ed.5). Yogyakarta: Andi

Zackham AND Elaine Goldsmith-Thomas. (2017). Second Act. http://www.secondact.movie/synopsis/ 